\title{
INDEX BY AUTHORS
}

Anderson, Albert . . Philosophical Obscurantism: Prolegomena to Hamann's Views on Language . . . 247

Beecher, Henry K. . . . . . Ingersoll Lecture: Response by a Physician 21

Clouse, Robert G. . . . Johann Heinrich Alsted and English Millennialism . . . . . . . . . . 189

Feingerg, Lawrence . . . . A Papyrus Text of I Kingdoms (I Samuel) 349

Fishwick, Duncan . . . . Genius and Numen . . . . . . . 356

JAvor, George . . . . . A Senecan Echo in Luther's Table-Talk . 430

KaUfman, Gordon D. . . . Ingersoll Lecture: Response by a Theologian . . . . . . . . . . 26

Klesv, RalPh Walter . . . . Old Readings in I Esdras: The List of Returnees from Babylon (Ezra $2 / /$ Nehemiah 7) . . . . . . . . . .

MaIER, Paul L. . . . . . The Episode of the Golden Roman Shields at Jerusalem . . . . . . . 109

McClendon, James WM., JR. . Can There Be Talk About God-and-theWorld? . . . . . . . . . . 33

McLain, Michael . . . . On Theological Models . . . . . 155

NIEbUhr, RIchard . . . . The Widened Heart . . . . . . . 127

Ozment, Steven E. . . . . Homo Viator: Luther and Late Medieval Theology . . . . . . . . . 275

Pahnke, Walter N. . . . . The Psychedelic Mystical Experience in the Human Encounter with Death.

PolzTN, RoBert . . . . . HWQYc and Covenantal Institutions in Early Israel . . . . . . . . . . 227

RUPP, GEORGE . . . . . . . The 'Idealism' of Jonathan Edwards . . 209

Rodes, Robert E., JR. . . . . The Last Days of Erastianism-Forms in the American Church-State Nexus . . 301

Rosenblatt, Jason P. . . . Celestial Entertainment in Eden: Book V of Paradise Lost . . . . . . . . . 411

Shenrei, James Donald . . A Comparative Study of The Synoptic Parallels in I Paraleipomena and I \& II Reigns .. . . . . . . 63

Smith, Constance I. . . . . Aelred's Immersion . . . . . . . . 429

SMITH, Rogert B. . . . . . . Orthogenesis and God-Omega . . . . . 397

Thundyin, Zacharias . . . Emerson and the Problem of Evil: Paradox and Solution... . . . . . . 51

Ward, RoY Bowen . . . Partiality in the Assembly: James 2:2-4 . 87 
Wertz, Dorotry . . . . . The Theology of Nominalism in the English Morality Plays . . . . . 371

WhitTAKer, JoHN . . . . Basilides on the Ineffability of God . . . 367

VAN Seters, JohN . . . . Jacob's Marriages and Ancient Near East Customs: A Re-examination . . . . . 377

Young, Archrbald M. . . . Some Aspects of St. Augustine's Literary Aesthetics, Studied Chiefly in $D e$ Doctrina Christiana . . . . . . . 289

Books Recerved . . . . . . . . . . . . . . . . . 123, 241, 375, 439

Summaries of Doctoral Dissertations . . . . . . . . . . . . . 431

Burkholder, John Richard, Religion in the First Amendment: A Social Theory Approach to Constitutional Interpretation; CarTLIDGE, Davm R., Competing Theologies of Asceticism in the Early Church; Isenberg, Sheldon, Studies in the Jewish Aramaic Translations of the Pentateuch; Janzen, Waldemar, 'Ašrê and $H o \hat{i} i$ in the Old Testament; KrStitch, Daniel S.B., St. John Chrysostom as the Theologian of Divine Philanthropy; Martin, Willram C., Christians in Conflict; Meyers, ErIC M., Jewish Ossuaries and Secondary Burials in their Ancient Near Eastern Setting; Reynolds, Chardes H., The Significance of Firth's Ideal Observer Theory for Theological Ethics; Reynolds, Roger E., Sacred Orders in the Early Middle Ages: Shifts in the Theology of the Lower and Higher Ecclesiastical Orders from Late Patristic Antiquity through the Early Middle Ages as Reflected in the Ordinals of Christ and Related Literature; Roberts, JIMmy J., The Early Akkadian Pantheon: A Study of the Semitic Deities Attested in Mesopotamia before Ur III; Schmiechen, Peter M., The Divine Love: A Study in the Doctrine of God and Theological Method in Friedrich Schleiermacher's The Christian Faith. 


\section{HARVARD THEOLOGICAL STUDIES}

XIX. AN ESSAY ON THE DEVELOPMENT OF LUTHER'S THOUGHT ON JUSTICE, LAW, AND SOCIETY. By F. Edward Cranz, xvi, 197 pages. 1958. $\$ 2.50$.

XXI. A SACRED CALENDAR OF ELEUSIS. By Sterling Dow and Robert F. Healey, S.J. 58 pages. 1965 . $\$ 2.00$.

XXII. THE PROTO-SINAITIC INSCRIPTIONS AND THEIR DECIPHERMENT. By William F. Albright. 45 pages. 1966. $\$ 2.00$.

XXIII. BIBLIOGRAPHY OF HEBREW PUBLICATIONS ON THE DEAD SEA SCROLLS, 1948-1964. By Michael Yizhar. 48 pages. 1967. \$2.50.

Above Studies available from the Harvard University Press, 79 Garden Street, Cambridge, Mass. 02138, U.S.A.

Back issues of the HTR [vols. 1-57 (1908-64)] are not available at the Office of the Harvard Theological Review or at the Harvard University Press. They can be obtained from the Kraus Reprint Corporation [16 East 46th Street, New York, N.Y., 10017] as follows:

Vols. 1-14 (1908-21): Clothbound $\$ 310.00$, paperbound $\$ 280.00$; per volume, paperbound $\$ 20.00$.

Vols. 15-52 (1922-59): Original edition, as far as available, per volume \$12.50. 


\section{Classic literature is always modern}

\section{THE LOEB \\ CLASSICAL LIBRARY}

7 HE great literature of the Greeks and Romans

I has remained alive throughout the centuries because of the deeply satisfying pleasure it has given to each new generation of readers. The Odyssey of Homer, the poems of Ovid, the philosophy of Plato, the adventures of Aeneas - these are old friends of the classroom. But many other books, by both familiar and less well-known authors, provide reading as stimulating today as it was two thousand years ago. The witty dialogues of Lucian, the brilliant comedies of Aristophanes, the travels of Strabo, and the botanical discoveries of Theophrastus, founder of modern botany, are only samples of the wide range of subjects included in the LobB Cuassical Library of over 360 titles.

In the Lorb Cuassical Library the original Greek or Latin text is printed on left-hand pages with a line-for-line translation on facing pages. Write for a descriptive catalogue. The price is uni-

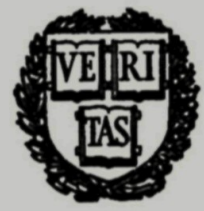
formly $\$ 4.00$ a volume.

\section{HARVARD UNIVERSITY PRESS CAMBRIDGE $38, \quad, \quad$ MASSACHUSETTS}

